\title{
Chemical composition and antioxidant activity of the essential oil of Croton dybowskii Hutch from Congo- Brazzaville
}

\author{
Tsiba Gouollaly ${ }^{1,2 \star}$, Kevin Bikindou ${ }^{3,4}$, Edmond Mabiangana ${ }^{4}$, Aubin Nestor Loumouamou ${ }^{3,4}$, \\ Sarrah Boumba ${ }^{1}$, Marie Claire Makambila ${ }^{1}$, Gilles Figuérédo ${ }^{5}$ and Pierre Chalard ${ }^{6,7}$ \\ ${ }^{1}$ Institut National de Recherche en Sciences de la Santé (IRSSA). Département de la Pharmacopée et Médecine \\ Traditionnelle. Laboratoire de Chimie des Biomolécules organiques et de Pharmacodynamie. \\ ${ }^{2}$ Unité de Chimie du Végétal et de la Vie (UC2V) Faculté des Sciences - Université Marien Ngouabi BP 69, Brazzaville, \\ Congo. \\ ${ }^{3}$ Equipe Pluridisciplinaire en Alimentation et Nutrition (EPRAN), Faculté des Sciences et Techniques, Université Marien \\ Ngouabi, BP 389, Brazzaville, \\ ${ }^{4}$ Herbier National «Institut National de Recherche en Sciences Exactes et Naturelles » (IRSERN), Cité Scientifique de \\ Brazzaville, BP 2400, Congo. \\ ${ }^{5}$ Laboratoire d'analyse des extraits végétaux et des arômes (LEXVA) Biopole, Clermont-Limagne, St. Beauzire, France. \\ ${ }^{6}$ Université Clermont Auvergne, SIGMA Clermont, Institut de Chimie de Clermont Ferrand, BP 10448, F-63000 \\ Clermont-Ferrand, \\ ${ }^{7}$ CNRS, UMR 6296, Institut de Chimie de Clermont-Ferrand, F-63178 Aubière, France.
}

Accepted 24 December, 2018

\begin{abstract}
The chemical composition of the essential oil of Croton dibowskii Hutch from Congo-Brazzaville was analyzed by GC/FID and GC/SM. The chemical profile remains, for the most part, dominated by the cyperene (15.1\%), borneol (12.5\%), (6.9)-guaiadiene (8.2\%), a-muurolene (7.9\%) and 1.8-cineole (6.7\%), representing in general $57.4 \%$ of sesquiterpene hydrocarbons and $23.8 \%$ of oxygenated monoterpne. We note in some respects, with a low content, the presence of monoterpenic hydrocarbons and sesquiterpenic oxygenated compounds of 5.0 and $3.0 \%$, respectively. The antioxidant activity on the DPPH turns out to be very limited, it reaches inhibition percentage of $35 \%$ from the concentration of $2000 \mu \mathrm{g} / \mathrm{ml}$ with a Cl50 estimated at $3000 \mu \mathrm{g} / \mathrm{ml}$.
\end{abstract}

Keywords: Antioxidant activity, chemical composition, Croton dybowskii, essential oil.

${ }^{*}$ Corresponding author. Email: gouollalyts@gmail.com.

\section{INTRODUCTION}

Croton dybowskii Hutch. (Euphorbiaceae) is a small tree, which is sometimes sarmentose, distributed along the coastal Lower Guinean (Figure 1) (Lebrun and Stork, 2012; Miabangana et al., 2017). Ecologically, C. dybowskii is a plant confined in inshore thickets from 2 to $6 \mathrm{~m}$ high, with typical species like Manilkara obovata (Sabine \& G. Don) J.H. Hemsl, in the form of enclaves in the grassy formations in Anadelphia hamata Stapf. The typical tree species of the tree and shrub stratum are: Baphia vili Cheek, Barteria nigritana Hook.f. subp. nigritana, Borassus aethiopum Mart., Chrysobalanus icaco L. subsp. icaco, Fegimanra africana (Oliv.) Pierre, Manilkara obovata J.H. Hemsl., Syzygium guineense (Willd.) DC. subsp. Guineense (Miabangana et al., 2017). The undergrowth is dominated by: Baphia leptostemma Baill. Subsp. leptostemma, C. dybowskii Hutch. Eugenia klaineana (Pierre) Engl. E. sumbensis Greves, Psychotria peduncularis (Salisb.) Steyrm (Miabangana et al., 2017).

Its roots with high aromatic smell are highly used as masticatory and in aqueous soaking for the sexual 


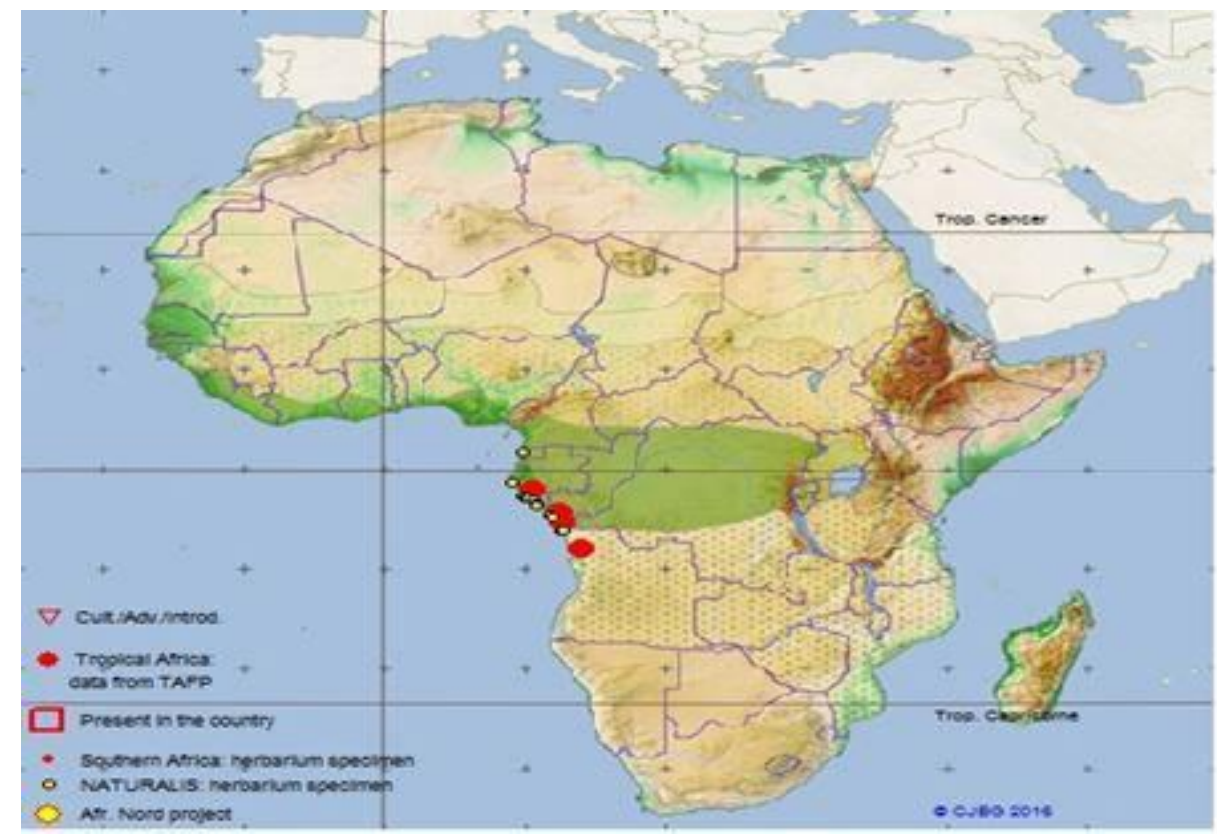

Figure 1. Geographical distribution of C. dybowskii Hutch. (Lebrun and Stork, 1991-2012).

asthenia and the pelvic pains treatment and also as a diuretic. The plant is threatened with the extinction due to its use as a consequence of its intensive marketing in the markets and bars in Brazzaville, Pointe-Noire and Kinshasa.

Previous studies focused on essential oils and isolated compounds made it possible to highlight some pharmacological properties on other Croton-type species: toxicologic (Fontenelle et al., 2008), antimicrobial (Simionatto et al., 2007; Baccelli et al., 2007; Kerntopf et al., 2008; Fontenelle et al., 2008; Daouda, 2015), molluscicide (Baccelli et al., 2007), antihypertensive and vasodilator (Guerrero et al., 2001), vasorelaxant (Daouda, 2015), cytotoxic and antitumor activity (Morales et al., 2005; Roenqsumran et al., 2002; Sandoval et al., 2002; Bezerra et al., 2009; Compagnane et al., 2010; Deore et al., 2009; Suganya et al., 2012), antioxidant activity (Sakina et al., 2016), insecticide, anti-microbial, anthelminthic, antimalarial, anti-inflammatory and leishmanicide (El Babili, 1997).

The chemical composition of the essential oils of other Croton-type species of various origins has already been carried out and the major constituents of its various tree species have been identified: $\beta$-caryophyllene (16.7\%), germacrene $D(14.7 \%)$ and borneol $(8.3 \%)$ of $C$. bonplandianus (Joshi et al., 2014), (E)-caryophyllene $(31.75 \%)$, germacrene-D $(22.57 \%)$ and $\alpha$-humulène $(7.42 \%)$ of C. hirtus (Turiel et al., 2013), $\beta$-pinene (16.9\%), a-pinene (16.5\%), curzerene (12.8\%) and germacrene D $(9.0 \%)$ of $C$. draconoides (Daouda. 2015), sesquicineole $(23.0 \%)$, dehydro-sesquicineole (13.8\%), $\beta$-caryophyllene $(7.9 \%), \beta$-bisabolol $(5.0 \%)$, germacrene D $(4.2 \%)$ and $\beta$-elemene $(4.1 \%)$ of $C$. urucurana
(Daouda. 2015), $\beta$-phellandrene (18.2\%), (E)- $\beta$-guaiene (16.5\%), $\alpha$-pinene $(10.4 \%),(Z)-\beta$-guaiene $(15.9 \%)$ and (E)-caryophyllene $(16.21 \%)$ of C. sonderianus (Giuliane et al., 2017), (E)-anethol (88.5\%) of C. zehntneri (Giuliane et al., 2017), bicyclogermacrene (48.9\%), $\beta$ caryophyllene (14.\%) and germacrene $D(12.6 \%)$ of $C$. isabelli (Giuliane et al., 2017), terpinen-4-ol (13.6\%), $\beta$ caryophyllene $(11.5 \%)$ and germacrene $D(7.6 \%)$ of $C$. pallidulus (Giuliane et al., 2017), $\beta$-pinene (39.0\%) and $\beta$ caryophyllene $(8.1 \%)$ of $C$. ericoides (Giuliane et al., $2017)$, cymene $(13.80 \%), 1.8$ cineole $(27.07 \%)$ and $\alpha-$ terpineol (6.87\%) of C. zambesicus, (Sakina et al., 2016), a-pinene $(20,98 \%)$, sabinene $(11,21 \%)$ and bicyclogermacrene (28\%) of C. argyrophylloides (De Souza et al., 2017), a-pinene, $\beta$-pinene (10\%), $(16,5 \%), \quad(E)$-caryophyllene $\quad(25,3 \%) \quad$ and bicyclogermacrene $(30.1 \%)$ of C. sincorensis, (De Souza et al., 2017), $\delta$-elemene $(12,8 \%)$ and $\beta$-elemene $(22,2 \%)$ of C. jacobinensis (De Souza et al., 2017), bicyclogermacrene (30.0\%), spathulenol (12.0\%) and sabinene $(11.0 \%)$ of C. argyrophylloides (Giuliane et al., 2017).

To the best of our knowledge, no chemical composition study of the essential oil of this plant has been carried out yet. Our objective in this present work is to study the chemical composition of the essential oil roots from $C$. dibowskii. Hutch and to evaluate its antioxidant power.

\section{MATERIALS AND METHODS}

\section{Vegetable material}

Croton dibowskii Hutch roots have been harvested in Congo- 


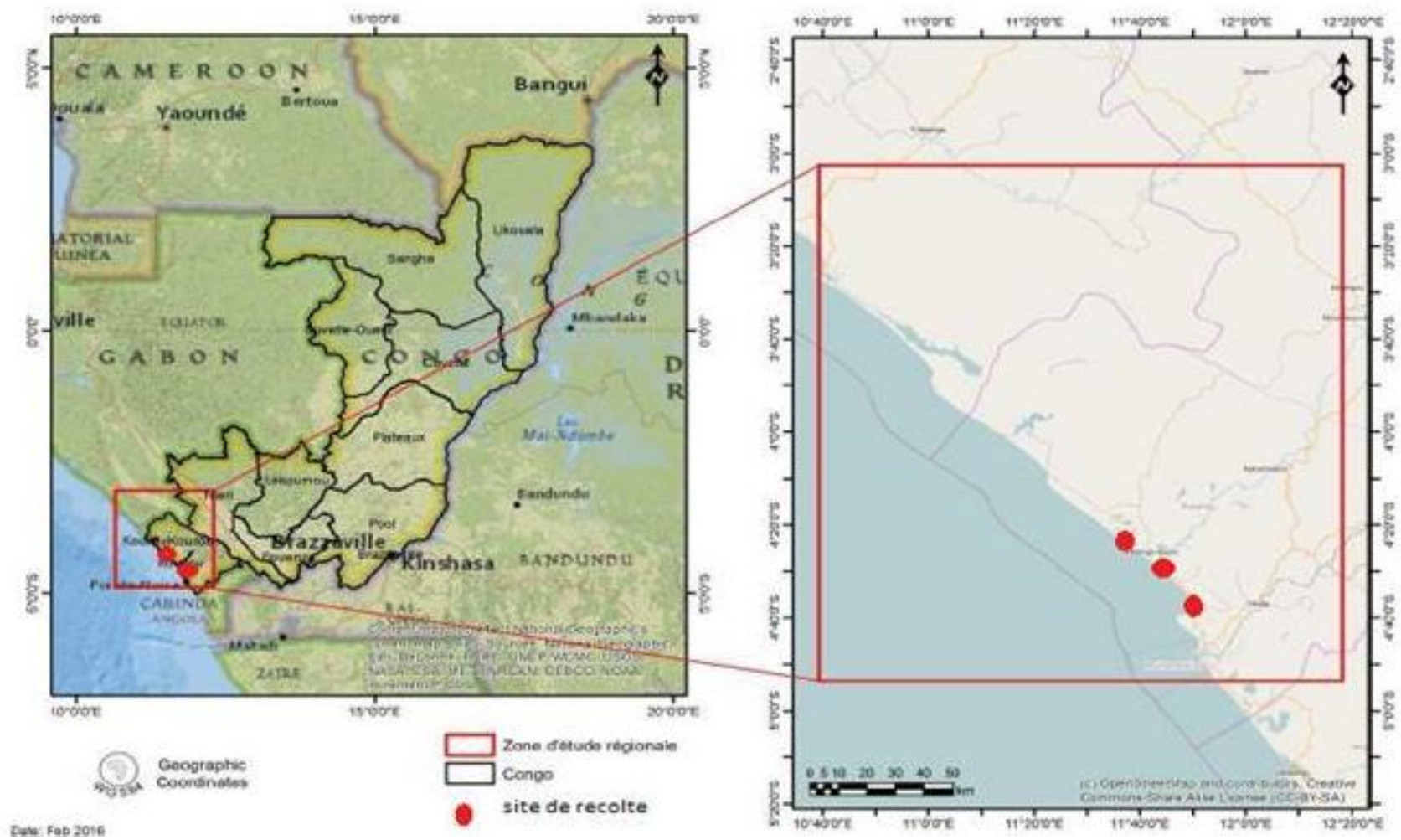

Figure 2. Map of the study area.

Brazzaville in the administrative department of Kouilou in Pointe Indienne (Figure 2) on the basis of the following map reference: S4 40.244 E11 48.861, Alt : $-14 \mathrm{~m}$. The different organs of the plant (Figure 3) have been compared with those of National Herbarium of the National Institute of Research in Exact and Natural Sciences (IRSEN) under number 188 (Miabangana et al., 2017).

The roots of the plant were dried at room temperature, for about a week. The dried vegetable was ground with an IKA-WERKE GmbhCO-KG, D-79219, Staufen-type device, with a sieve of granulometry $0.25 \mathrm{~mm}$.

\section{Method of production of the essential oil}

The essential oil was obtained by vapohydrodistillation using Clevenger type apparatus (Clevenger, 1928). Each time, $300 \mathrm{~g}$ of vegetable material, consisting either only roots or stems, leaves and young flowers were placed in a flask with $500 \mathrm{ml}$ of water and subjected to distillation. The organic phase from the distillation was separated from the aqueous phase by extraction with diethyl ether. The organic phase thus obtained was dried over anhydrous sodium sulfate to remove traces of water and the essential oil was recovered after evaporation of the diethyl ether and then move on to the chromatographic analysis immediately.

\section{Analysis by gas chromatography (GC)}

The quantitative analysis of the essential oil was carried out using an Agilent gas chromatograph model 6890 equipped with a DB5 column $(20 \mathrm{~m} \times 0.18 \mathrm{~mm} ; 0.18 \mu \mathrm{m})$. The oven temperature was programmed to $50^{\circ} \mathrm{C}$ for $3.2 \mathrm{~min}$, then heated to $300^{\circ} \mathrm{C}$ at a rate of $10^{\circ} \mathrm{C} / \mathrm{min}$. The temperatures of the injector and the flame ionization detector (FID) were maintained at $280^{\circ} \mathrm{C}$. The essential oils were diluted in acetone to $3.5 \%(\mathrm{v} / \mathrm{v})$ and injected in split mode $(1 / 60)$; hydrogen was used as the carrier gas $(1 \mathrm{ml} / \mathrm{min})$, and the injection volume was $1 \mu \mathrm{l}$. At the same time, a solution of $n$-alkanes (C8C30) was analyzed under the same conditions to calculate retention indices (RI) using the Van den Dool and Kratz equation (Van Del Dool and Kratz, 1963). The relative concentrations of the compounds were calculated from the peak area obtained by gas chromatography without using correction factors.

\section{Analysis by coupling gas chromatography and mass spectrometry (GC-MS)}

Qualitative analysis was performed using an Agilent gas chromatograph model 7890 coupled to a Agilent mass spectrometer model 5975 equipped with a DB5 MS column $(20 \mathrm{~m} \times$ $0.18 \mathrm{~mm} ; 0.18 \mu \mathrm{m})$. The oven temperature was $50^{\circ} \mathrm{C}$ and remained constant for $3.2 \mathrm{~min}$; then, it was increased to $300^{\circ} \mathrm{C}$ at a rate of $8^{\circ} \mathrm{C} / \mathrm{min}$. The injector temperature was $280^{\circ} \mathrm{C}$. Ionization was obtained by electron impact at $70 \mathrm{eV}$, and the electron multiplier was maintained at $2200 \mathrm{eV}$. The temperature of the ion source was $230^{\circ} \mathrm{C}$. Mass spectral data were acquired in the scan mode in the range $\mathrm{m} / \mathrm{z} 33-450$. The flow of carrier gas (helium) was set at 0.9 $\mathrm{ml} / \mathrm{min}$. The identification of the compounds was made by comparison of their mass spectra and RI with those of libraries such as Adams (2012), NIST (2008), König et al. (2001) and those of laboratory.

Determination of the antioxidant activity with 2.2-diphenyl-1picrylhydrazyl (DPPH) radical scavenging method

Radical scavenging using DPPH radicals is the main mechanism which antioxidants act in food. The DPPH method as summarized 


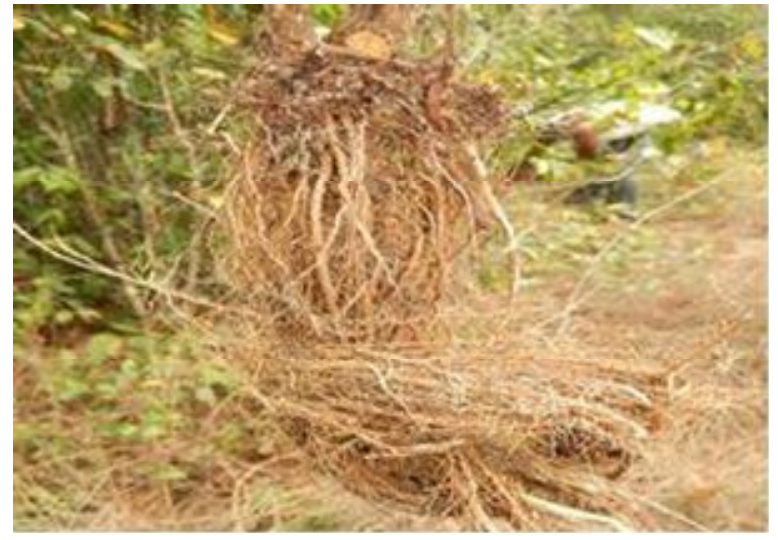

a

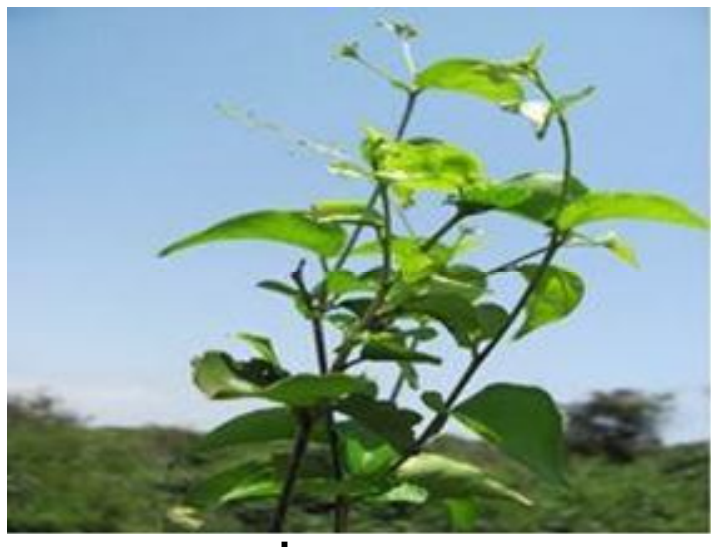

b

Figure 3. Different organs of Croton dybowskii Hutch. (a) Roots, (b) small tree in the inshore thicket.

below was introduced nearly 50 years ago by Blois (1958).

The free radical-scavenging activity of extracts was measured by 2.2-diphenyl-2-picrylhydrazyl (DPPH). A solution of DPPH in methanol $(24 \mu \mathrm{g} / \mathrm{ml})$ was prepared and $2 \mathrm{ml}$ of this solution was added to $50 \mu \mathrm{l}$ of extracts solution in methanol at different concentrations $(250,500,1000$ and $2000 \mu \mathrm{g} / \mathrm{ml})$. Then, the absorbance was measured at $517 \mathrm{~nm}$ in a spectrophotometer. In the original method, a reaction time of 30 min was recommended. Percent inhibition of the DPPH radical by the samples was calculated according to the formula of Yen and Duh (1994). Scavenging effect $(\%)=\left[\left(A_{0}-A_{1}\right) / A_{0}\right] \times 100$, where $A_{0}$ was the absorbance of the control sample (without essential oil) and $A_{1}$ was the absorbance in the presence of the sample.

\section{RESULTS AND DISCUSSION}

\section{Chemical composition}

The extraction gave yellow essential oil which yielded $0.4 \%$. Its chemical essential, reported in Table 1 , showed 53 identified compounds representing $90.8 \%$ of the chemical composition of the essential oil. The chromatographic profile remains dominated, for the most part, by cyperene (15.1\%), borneol $(12.5 \%)$, (6.9)guaaiadiene $(8.2 \%)$, a-muurolene $(7.9 \%)$ and 1.8 -cineol $(6.7 \%)$. This essential oil is generally characterized by its high content in sesquiterpene hydrocarbons and oxygenated monoterpenes, which represent respectively 57.4 and $23.8 \%$, that is, more than half of the total chemical composition of the essential oil. On the other hand, monoterpene hydrocarbons and oxygenated sesquiterpenes represent the smallest proportion that is 5.0 and $3.0 \%$.

In addition, we noted the presence of epi-13-manool oxide with a content of $0.9 \%$, corresponding to the only diterpenic compound present in the essential oil. It is appropriate to emphasize that the unidentified compounds represent $9.8 \%$ of the total chemical composition of the essential oil. Taken individually, their content does not exceed $3.0 \%$. This chemical composition is close in general to the Croton-type essential oils (Joshi et al., 2014; Giuliane et al., 2017) by its richness in sesquiterpene hydrocarbons compounds but different from the latter by the individual content in cyperene (15.1\%) and (6.9)-guaiadiene (8.2\%), sesquiterpene hydrocarbons have never been reported in these latter. It is all the more different, by its quite high content in borneol (12.5\%), compounds reported in some species (Joshi et al., 2014; Giuliane et al., 2017) of its kind but with smallest content proportion.

This essential oil is totally different from the oils of $C$. zehntneri (Giuliane et al., 2017), for its richness in (E)anethol (88.5\%), of C. zambesicus (Sakina et al., 2016), for its specific richness in aromatic monoterpene (cymene at $13.80 \%)$ and oxygenated (1.8 cineole at $27.07 \%)$ and l'a-terpineol at $6.87 \%$ ) and of $C$. hirtus, $C$. urucurana, $C$. isabelli, C. argyrophylloides, C. jacobinensis for their specific richness in sesquiterpenic compounds (Turiel et al., 2013; Daouda, 2015; Giuliane et al., 2017; De Souza et al., 2017).

\section{Antioxidant activity}

The antioxidant activity of the $C$. dybowskii Hutch essential oil in the relation to $\mathrm{DPPH} \cdot$ radical was estimated using spectrophotometer on watching the reduction of this radical which is accompanied by its transition from violet to $(\mathrm{DPPH} \bullet)$ to yellow $(\mathrm{DPPH}-\mathrm{H})$ measurable at $517 \mathrm{~nm}$.

The results of the antioxidant activity of the essential oil of C. dybowskii Hutch presented in Figure 3 show inhibition of $35 \%$ at the highest concentration (2000 $\mu \mathrm{g} / \mathrm{ml}$ ) with inhibitory concentration of $50 \%$ estimated at $3000 \mu \mathrm{g} / \mathrm{ml}$. This power to reduce the free radicals observed in the present study could be explained by its chemical composition dominated by the cyperene (15.1\%), borneol (12.5\%), (6.9)-guaiadiene (8.2\%), amuurolene $(7.9 \%)$ and 1.8-cineol (6.7\%). This 
Table 1. Chemical composition of the essential oil from $C$. dybowskii Hutch roots.

\begin{tabular}{|c|c|c|c|}
\hline No. of order & $\mathbf{R I}$ & Constituents $\left(^{*}\right)$ & $\%$ \\
\hline 01 & 933 & $\alpha$-pinene & 1.1 \\
\hline 02 & 950 & camphene & 0.1 \\
\hline 03 & 973 & sabinene & 0.1 \\
\hline 04 & 980 & $\beta$-pinene & 2.2 \\
\hline 05 & 1025 & o-cymene & 1.1 \\
\hline 06 & 1029 & Limonene & 0.1 \\
\hline 07 & 1030 & 1.8-cineol & 6.7 \\
\hline 08 & 1060 & $\mathrm{y}$-terpinolene & 0.1 \\
\hline 11 & 1068 & sabinene cis-hydrate & 0.1 \\
\hline 09 & 1089 & Terpinolene & 0.1 \\
\hline 10 & 1096 & Linalool & 0.1 \\
\hline 12 & 1146 & Camphor & 0.1 \\
\hline 13 & 1150 & hydrate camphene & 0.1 \\
\hline 14 & 1166 & Borneol & 12.5 \\
\hline 15 & 1185 & terpinen-4-ol & 1.3 \\
\hline 16 & 1196 & $\alpha$-terpineol & 2.4 \\
\hline 17 & 1217 & Trans-carveol & 0.2 \\
\hline 18 & 1245 & carvacrol methyl ether & 0.4 \\
\hline 19 & 1294 & undecanone (2-) & 0.1 \\
\hline 21 & 1370 & guaiadiene (6.9)- & 8.2 \\
\hline 22 & 1376 & Isoledene & 0.2 \\
\hline 23 & 1377 & $\alpha$-copaene & 1.5 \\
\hline 24 & 1381 & $\beta$-patchoulene & 0.6 \\
\hline 25 & 1391 & $\beta$-elemene & 0.7 \\
\hline 26 & 1392 & Sativene & 0.8 \\
\hline 27 & 1399 & Cyperene & 15.1 \\
\hline 28 & 1408 & amorpha -4.7(11)-diene & 0.9 \\
\hline 29 & 1418 & $\alpha$-santalene & 0.8 \\
\hline 30 & 1420 & a-barbatene & 1.7 \\
\hline 31 & 1423 & $\beta$-cedrene & 1.7 \\
\hline 32 & 1431 & cis-thujopsene & 1.3 \\
\hline 33 & 1441 & Aromadendrene & 1.2 \\
\hline 34 & 1453 & $\mathrm{NI}$ & 1.2 \\
\hline 35 & 1460 & allo aroamadendrene & 0.4 \\
\hline 36 & 1477 & trans-cadina- $1(6), 4$-diene & 0.2 \\
\hline 37 & 1492 & cis- $\beta$-guaiene & 2.4 \\
\hline 38 & 1493 & $\delta$-selinene & 1.6 \\
\hline 39 & 1496 & Valencene & 0.6 \\
\hline 40 & 1497 & Viridiflorene & 0.5 \\
\hline 41 & 1500 & a-muurolene & 7.9 \\
\hline 42 & 1506 & $\beta$-bisabolene & 0.5 \\
\hline 43 & 1509 & Cuparene & 0.5 \\
\hline 44 & 1512 & $\mathrm{NI}$ & 1.1 \\
\hline 45 & 1523 & $\beta$-sesquiphelandrene & 0.2 \\
\hline 46 & 1539 & $\alpha$-cadinene & 7.5 \\
\hline
\end{tabular}


Table 1. Continues.

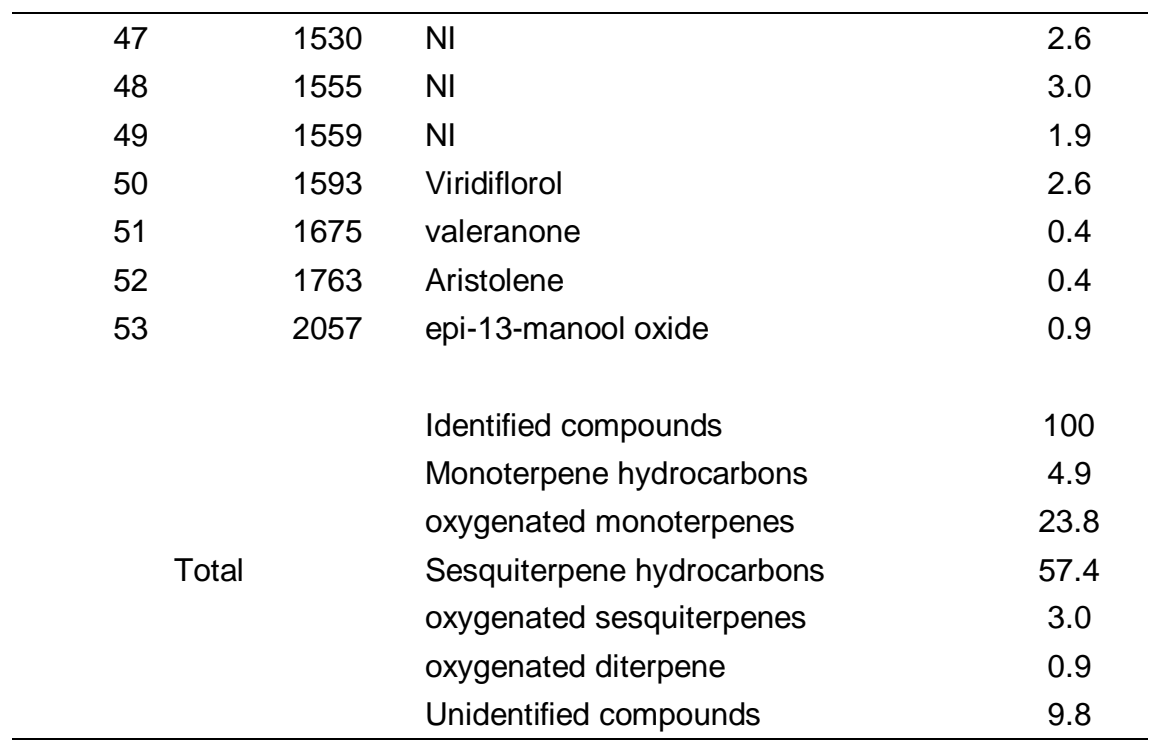

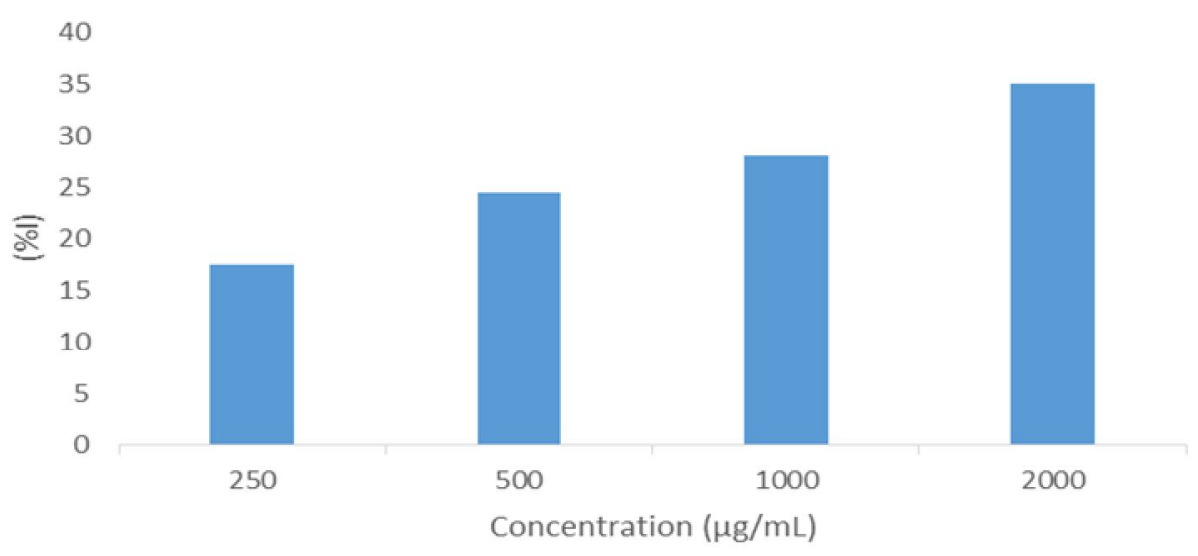

Figure 4. Radical scavenging activity of DPPH by the essential oil.

antioxidant activity is comparable to that of Sakina and al., (2016) on C. zambesicus. In fact, these authors had inhibitory concentration of $50 \%$ at 4200 to $3000 \mu \mathrm{g} / \mathrm{ml}$ estimated in the present study. They explained the activity of $C$. zambesicus by the presence of cymene (aromatic compound) identified at $13.80 \%$ and at 1.8 cineole and l'a-terpineol two oxygenated monoterpenes identified at $27.07 \%$ and $6.87 \%$ in the plant respectively. The latter used a dilution technique on 96-well plate (Molyneux, 2004). (Figure 4).

\section{CONCLUSION}

The chemical composition of the $C$. dybowskii essential oil showed a dominance of sesquiterpenic hydrocarbons compounds: cyperene (15.1\%), (6.9)-
Guaiadiene (8.2\%), a-cadinène (7.5\%) and a-muurolene $(7.9 \%)$ followed by monoterpenic oxygenated compounds: borneol (12.5\%), and 1.8-cineol (6.7\%). In addition, we note the presence of epi-13-manool oxide with a content of $0.9 \%$ corresponding to the only diterpenic compound present in the essential oil. This chemical composition is close to essential oils Crotontype species ( $C$. bonplandianus and $C$ pallidulus) by its richness combined in sesquiterpene hydrocarbons and oxygenated monoterpnes and differs from the other Croton-type species (C. zehntneri, hirtus, C. urucurana, $C$. isabelli and de $C$. argyrophylloides) for their specific richness in (E)-anethol and in sesquiterpenic compounds. The antioxidant activity on the DPPH of the C. dybowskii Hutch essential oil showed a very low inhibition, not exceeding $35 \%$ at the concentration of $2000 \mu \mathrm{g} / \mathrm{ml}$, this activity is comparable to some Croton-type species. 


\section{REFERENCES}

Adams RP, 2012. Identification of Essential Oils by Capillary Gas Chromatography/mass Spectroscopy. Allured, Carol Stream, IL.

Baccelli C, Navarro I, Block S, Abad A, Morel N, Quetin-Leclercq J, 2007. Vasorelaxant activity of diterpenes from Croton zambesicus and synthetic trachylobanes and their structure - Activity relationships. J Nat Prod, 70(6): 910-917.

Bezerra DP, Marinho Filho JD, Alves AP, Pessoa C, de Moraes MO, Pessoa OD, 2009. Antitumor activity of the essential oil from the leaves of Croton regelianus and its component ascaridole. Chem.Biodivers, 6(8): 1224-1231.

Blois MS, 1958. Antioxidant determinations by the use of a stable free radical. Nature, 181: 1199-1200.

Compagnane RS, Chavez K, Mateu E, Orsini G, Arvelo F and Suarez Al, 2010. Composition and cytotoxic activity of essential oils from Croton matourensis and Croton micans from Venezuela. Rec Nat Prod, 4(2): 101-108.

Daouda T, 2015. Etudes chimique et biologique des huiles essentielles de quatre plantes aromatiques medicinales de côte d'ivoire. Thèse de Doctorat. Université Félix Houphouët Boigny de Cocody-Abidjan.; $154 \mathrm{p}$.

De Souza GS, Bonilla O H, De Lucena E M, Barbosa PY, 2017. Chemical composition and yield of essential oil from three Croton species. Ciencia Rural, 147(8).

Deore SL, Khadabadi SS, Baviskar BA, Khadabadi SS, Khangenbam RA, Koli US, 2009. In vitro Antioxidant activity and Phenolic Content of Croton caudatum. Int J Chem Tech Res, 1(2): 174-176.

El Babili F, 1997. Etude phytochimique et Evaluation d'Activités Biologiques de Diterpenes de Croton campestris st. hil. (Euphorbiaceae). Thèse de doctorat. Institut National Polytechnique de Toulouse. 279p.

Fontenelle RO, Morais SM, Brito EH, Brilhante RS, Cordeiro RA, Nascimento NR, Kerntopf MR, Sidrim JJ, Rocha MF, 2008. Antifungal activity of essential oils of Croton species from the Brazilian Caatinga biome. J Appl Microbiol, 104(5): 12-16.

Giuliane SS, OH Bonilla, EM Pereira de Lucena, Barbosa YP, 2017. Chemical composition and yield of essential oil from three Croton species. Ciencia Rural, 47, 8.

Guerrero MF, Puebla P, Carron R, Martın ML, Arteaga L, San Roman L., 2001. Assessment of the antihypertensive and vasodilator effects of ethanolic extracts of some Colombian medicinal plants. 80 (2002) 37-42.

Joshi RK, 2014. Chemical composition of the essential oil of Croton bonplandianus from India. Nat Prod Commun, 9(2): 269-270.

Kerntopf MR, Sidrim JJ, Rocha MF, 2008. Antifungal activity of essential oils of Croton species from the Brazilian Caatinga biome. $\mathrm{J}$ Appl Microbiol, 104(5): 1383-1390.

König WA, Hochmuth DH, Joulain D, 2001. Terpenoids and Related Constituents of Essential Oils. Library of Mass Finder 2.1. Institute of Organic Chemistry, Hamburg.

Lebrun JP, Stork AL, 1991-2012. Enumération des plantes à fleurs d'Afrique tropicale. Conservatoire et Jardin botaniques de la Ville de Genève, 4 volumes. http://www.villege.ch/musinfo/bd/cjb/africa/recherche.php?langue=fr).

Miabangana ES, Nsongola G, Orban B, Van Rooyen M, Van Rooyen $\mathrm{N}$, Gaugris J, 2017. Analyse floristique et phytogéographique de la végétation du littoral et sublittoral dans le Kouilou (République du Congo). 206-217.

Molyneux P, 2004. The use of the stable free radical diphenylpicrylhydrazyl (DPPH) for estimating antioxidant activity. Songklanakarin $J$ Sci Technol; 26(2): 211-219.

Morales A, Perez PP, Mendoza R, Compaqnone R, Suarez Al, Arvelo $F$, 2005. Cytotoxic and proapoptotic activity of ent-16 $\beta-17 \alpha-$ dihydrokaurane on human mammary carcinoma cell line MCF-7. Cancer Lett, 218(131): 109-116.

National Institute of Standards and Technology (NIST), 2008. Spectral Database for Organic Compounds. NIST WebBook: http//webbook.nist.gov/chemistry.
Roenqsumran S, Musikul K, Petsom A, Vilaivan T, Sanqvanich P, Pornpakakul S, 2002. Croblongifolin, a new anticancer clerodane from Croton oblongifolius. Planta Med, 68(3): 274-277.

Sakina Y, Randa B, Tzvetomira T, Herve S, 2016. Chemical composition, antiproliferative, antioxidant and antibacterial activities of essential oils from aromatic plants growing in Sudan. Asian Pac J Trop Med, 10(6): 1-21.

Sandoval M, Okuhama NN, Clark M, Angeles FM, Lao J, Bustamante $S$, 2002. Sangre de grado Croton palanostigma induces apoptosis in human gastrointestinal cancer cells. J Ethnopharmacol, 80(2-3): 121129.

Simionatto E, Bonani VFL, Morel AF, Poppi NR, Raposso Junior JL, Stuker CZ, 2007. Chemical composition and evaluation of antibacterial and antioxidant activities of the essential oil of Croton urucurana Baillon (Euphorbiaceae) stem bark. J Braz Chem Soc, 18(5): 879-885.

Suganya DP, Saravana kumar M, Mohan Das S, 2012. In vitro antiproliferative effects of anthocyanins extracted from red sorghum (Sorghum bicolor) bran on human larynx carcinoma cell line. Int $\mathrm{J}$ Pharm Pharm Sci, 4(4): 532-536.

Turiel NA, Ribeiro AF, Carvalho EE, Domingos VD, Lucas FC, Carreira LM, Andrade EH, Maia JG, 2013. Essential oils composition of croton species from the Amazon. Nat Prod Commun, 8(10): 1471-1472.

Van Del Dool H, Kratz PD, 1963. A generalization of the retention index system including lenear temperature programmed gas-liquid partition chromatography. J Chromatograph, 11:463-471.

Yen GC, Duh PD, 1994. Scavenging effect of methanolic extracts of peanut hulls on free-radical and active-oxygen species. J Agric Food Chem, 42: 629-632.

Citation: Gouollaly T, Bikindou K, Mabiangana E, Loumouamou AN, Boumba S, Makambila MC, Figuérédo G, Chalard P, 2019. Chemical composition and antioxidant activity of the essential oil of Croton dybowskii Hutch from Congo-Brazzaville. Adv Med Plant Res, 7(1): 1-7. 